Г. Гордашевська, Л. Галушко // Проблеми підготовки сучасного вчителя. - 2014. - № 9 (2). - С. 88-94.

5. Бистрова Ю. В. Інноваційні методи навчання у вищій школі України / Ю. В. Бистрова // Право та інноваційне суспільство. - 2015. № 1. - С. 27-33.

6. Леонтьєва В. М. Культуротворчість: природа, системи, процеси : автореф. дис. ... д. філос. наук : спец. 09.00 .04 / В. М. Леонтьєва. Харків, 2004. - 32 с.

7. Сидоренко Н. В. Інноваційна культура як вищий прояв загальнокультурних професійних та особистісних якостей учителя / Н. В. Сидоренко // Педагогічні науки: теорія, історія, інноваційні технології. - 2014. - № 3. - С. 337-346.

DOI https://doi.org/10.30525/978-9934-26-040-7-48

\title{
ОСНОВНІ ПРИЧИНИ ПОШИРЕННЯ КОРУПЦІЇ В УКРАЇНІ
}

Яфонкіна І. П.

кандидат політичних наук, викладач

Ірпінського державного коледжу економіки та права

м. Ірпінь, Київська область, Украӥна

\section{Яфонкін А. О.}

кандидат юридичних наук, дочент, доиент кафедри військової підготовки Університету державної фіскальної служби Украӥни м. Ірпінь, Київська область, Украӥна

\section{Шевчук В. А.}

кандидат юридичних наук, дочент, завідувач кафедри військової підготовки Університету держсавної фіскальної служби України м. Ірпінь, Київська область, Украӥна

Слід зазначити, що в Україні немає жодної сфери суспільного життя, де рівень корупції не досяг би тотальних масштабів. 
Необхідно визнати, що за 2020 рік показники України в Індексі сприйняття корупції (Corruption Perceptions Index - CPI) виросли на 3 бали. Із 33 балами зі 100 можливих ми отримали 117 місце з 180 країн у списку СРІ. Поруч із нами у рейтингу Єгипет, африканська Есватіні (Свазіленд), Непал, Сьєрра-Леоне та Замбія - всі ці країни так само у CPI-2020 набрали по 33 бали [1].

Обговорюючи корупцію в Україні, високопоставлений європейський чиновник напередодні саміту Україна - СС відмітив, що є ряд країн $\mathrm{CC}$, які значно менш корумповані, ніж Україна, але там на багато більше тих, хто був засуджений за корупцію. Десь в системі щось не так, щось не працює в плані досягнення результатів [2].

У Свропейському союзі вважають, що в Україні процес реформ гальмує дуже поширена корупція. Українські ключові інститути повинні мати сильне і незалежне керівництво і мати можливість виконувати свою роботу без політичного, економічного чи іншого втручання [3].

Відомо, що дослідженням корупційних проявів, причин їх виникнення, поширення, заходів боротьби та протидії корупції, присвячено багато наукових робіт як зарубіжних, так і вітчизняних вчених.

Різні аспекти проблеми протидії корупції були предметом досліджень таких вітчизняних науковців, як Заброда Д.Г., Коваль М.В., Литвин Н.А., Мельник М.І., Новицький А.М., Рябченко О.П., Тильчик В.В., Яфонкін А.О., Яцків I.I. та інші.

Безпосередньо ряд проблемних питань поширення корупції були предметом дослідження різних галузей права: кримінального права, адміністративного права, митного права, 3 позиції державного управління та ін. [4].

Водночас, аналіз вищезгаданих праць вчених, наукової літератури, вивчення досвіду боротьби з корупцією в Україні та в зарубіжних країнах, останні показники корупції за даними «Індексу сприйняття корупції-2020» дає нам підстави стверджувати, що за рівнем корупції Україна посідає одне із останніх місць серед країн Європи та у світі. Поряд із іншими причинами низького стану економічного розвитку держави, падіння рівня життя українців, обмеження прав і свобод людини і громадянина, корупція відіграє вкрай негативну роль для економічного росту держави, поліпшення життя громадян держави.

Вищевикладене дає нам змогу узагальнити причини поширення корупції в державі яка, незважаючи на досить велику вітчизняну законодавчу базу та наявність нових антикорупційних органів, продовжує свій нескінченний шлях. 
Слід зазначити, що науковці досліджують причини виникнення та розповсюдження корупції та пропонують науково - обгрунтовані шляхи іiі подолання. Однак, практика законотворчості свідчить про те, що при прийнятті нових законів або внесенні змін та доповнень до існуючого законодавства законотворці не враховують наукову складову, що негативно впливає на якість нормативно-правового акту та залишає ніши для корупційних дій.

На нашу думку, корупція в Україні буде поширюватися, допоки у законодавчій владі більшість не буде становити люди не пов'язані 3 існуючими олігархічними кланами. Олігархічна ж політична система унеможливила їх потрапляння шляхом створення високого грошового залогу (десять мінімальних окладів) для кандидатів в депутати до Верховної Ради [5]. Тим самим фіксуючи у владних структурах лише своїх прибічників, які в свою чергу лобіюють прийняття нормативноправових актів в інтересах тих самих олігархів та олігархічних груп. Лобістами в Україні, як правило, називають політиків, котрі намагаються відстояти вузькі інтереси окремих фінансових або інших груп на шкоду іншим. Причому ці політики можуть бути як депутатами парламенту, так і міністрами уряду [6. с. 72].

На нашу думку, основними причинами поширення корупції $є$ :

- злиття бізнесу та влади;

- недосконале вітчизняне законодавство в якому, внаслідок низької антикорупційної експертизи нормативно-правових актів, залишається можливість здійснення корупційних діянь;

- залежність антикорупційної інфраструктури держави від міжнародних організацій;

- низький рівень життя більшості населення держави;

- подвійне тлумачення правоохоронними органами відповідальності за порушення антикорупційного законодавства для різних верств населення;

- відсутність значних судових вироків щодо покарання корупціонерів високого рівня;

- недостатній відомчий контроль за суб’єктами корупції;

- відсутність переслідування корупціонерів, які перетнули кордони України та відкрито використовують незаконно набуті гроші в зарубіжних країнах, правоохоронними органами цих країн, за виключенням США. Спроби з'ясування походження їх багатства вони називають політичними переслідуваннями;

- відсутність дієвого контролю за використанням грошової допомоги Україні від міжнародних організацій та держав. 
Підсумовуючи вищесказане слід, що для ефективної боротьби 3 поширенням корупції в Україні необхідно запровадити досвід боротьби 3 корупцією передових зарубіжних країн. Не можна боротися 3 поширенням корупції методом спортивної риболовлі «Спіймаввідпусти».

Методи публічного покарання за значущі корупційні правопорушення (як приклад можна навести країну Китай), на нашу думку, матимуть більш дієвий результат ніж застосування дисциплінарної, адміністративної відповідальності.

\section{Література:}

1. Індекс сприйняття корупції-2020 URL: https://ti-ukraine.org/ research/indeks-spryjnyattya-koruptsiyi-2020/.

2. В ЕС говорят об опасности риска сворачивания борьбы с коррупцией в Украине : Інформаційне агентство «Інтерфах-Україна» від 05. 10. 2020. URL: https://interfax.com.ua/news/political/692989.html.

3. Реформи в Україні продовжує гальмувати дуже поширена корупція - виступ від імені Борреля в Європарламенті: Інформаційне агентство «Інтерфах-Україна» від 10.02.2021. URL: https://ua.interfax.com.ua/news/general/722391.html.

4. Яфонкін А.О. Адміністративно-правові заходи боротьби 3 корупцією серед державних службовців в Україні: автореф. десерт. на здобуття наук. ступ. канд. юридичних наук зі спец. 12.00.07 / А.О. Яфонкін. - Національний університет державної фіскальної служби України - Ірпінь, 2013. - 20 с.

5. Про грошову заставу на проміжних виборах народного депутата України в одномандатному виборчому окрузі № 208 (Чернігівська область), призначених на 25 жовтня 2020 року: Постанова ЦВК від 1 вересня 2020 року № 2136. URL: https://zakon.rada.gov.ua/laws/show/ v0213359-20\#Text.

6. Гросфель Е. Цивилизованный лоббизм как антикоррупционная технология / Е. Гросфельд. - Політичний менеджмент, 2013. № 59. - C. 70-77. 